capacity - a period of about $10 \mathrm{~min}$. The gas remaining in the spirometer was then collected and analysed. The results of the analysis of these samples are presented in Table 1.

Table 1. RESULTS OF ANALYSkS OF GAS SAMPIES DRAWN AFTer THE

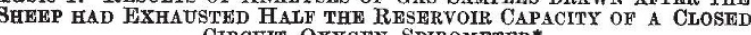

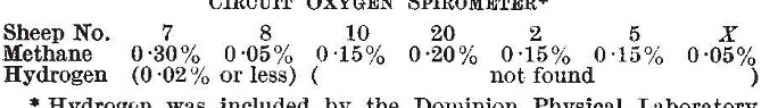
and is presented here for general interest.

There was no possible way in which the methane could have entered the spirometer other than from the lungs of the sheep. However, in view of the fact that in tracheotomized sheep some of the eructated gases flow back down the trachea-this was believed to be an original observation-the presence of traces of methane in the pulmonary system may have been due to residues from previous eructations. As the spirometer graphs used cannot be ruled to a greater accuracy than $0.05 \mathrm{l}$, a possible volume error of at the most $3 \mathrm{ml}$. of methane per $5 \mathrm{~min}$. is considered to be low enough to be ignored in these experiments.

This work was supported by the Research Committee of the University of New Zealand. Particular thanks are due to the Director of the Dominion Physical Laboratory, Wellington, for offering the necessary laboratory staff and facilities.

Massey Agricultural College,

\section{E. Cresswell*} New Zealand.

* Present address: The Rowett Research Institute, Bucksburn, Aberdeen, Scotland.

'Brody, S., "Bioenergeties and Growth", 315 (Reinhold, New York, 1945).

2 Ritzman, E. G., and Benedict, F. G., Carn. Inst. Wash. Pub., 494 25 (1938), citing Klein, W., Biochem. Zeitzch., 72, 169 (19i6),

' Blaxter, K. L., cited from Hammond, J., "Progress in the Physiology of Farm Animals", 26 (Butterworths, London, 1954).

- Cresswell, E., Nature, 179, 1139 (1957); Ph.D. thesis (1958), Massey Agricultural College Library, New Zealand.

\section{Erythropoietine Production in the Dog}

AN erythropoiesis-stimulating factor has been reported present in the plasma of numerous animals including the $\operatorname{dog}^{1}$. The $d \log$, although readily available and a convenient source of relatively large volumes of plasma, has been utilized sparingly ${ }^{2}$. The present study was made in order that the hæmo. poietic factor might be determined in the dog following exposure of the animal to various experimental procedures which are known to affect production of the factor in other species.

Five normal adult mongrel female dogs were placed in each of the following donor groups and subjected to the procedure indicated: group 1, untreated, healthy animals used as controls ; group 2, hæmorrhage, $20 \mathrm{ml} . / \mathrm{kgm}$./day for 4 days ; group 3, phenylhydrazine hydrochloride, $2 \cdot 5$ per cent, adjusted to $p H \mathbf{H} \cdot \mathbf{0}$, administered subcutaneously, $7.5 \mathrm{mgm} . / \mathrm{kgm}$. $/$ day, until the hrmoglobin concentration declined to $3 \cdot 5-5 \cdot 0 \mathrm{gm} . / 100 \mathrm{ml}$.; group 4, the dog maintained in a closed chamber, in which the gases were mixed by a fan, with carbon dioxide being absorbed by soda lime. A mixture of 9 per cent oxygen-91 per cent nitrogen was admitted at a rate of 6 litres/min. for $24 \mathrm{hr}$.

At the end of the experimental period, each animal was bled, and 'protein-free' plasma prepared Table 1. Effect of 'Protein-Fren' Plasma of Dog on Red Cell

\begin{tabular}{|c|c|c|c|c|}
\hline (Mean $=S . E)$. & $\begin{array}{l}\text { Hæmo- } \\
\text { globin } \\
\text { (gm./ } \\
100 \mathrm{ml} .)\end{array}$ & $\begin{array}{l}\text { Hæmato- } \\
\text { crit } \\
\text { (per cent) }\end{array}$ & $\begin{array}{l}\text { Red blood } \\
\text { count } \\
\text { (mill./ } \\
\text { c.mm.) }\end{array}$ & $\begin{array}{c}\text { Retics. } \\
\text { (per cent) }\end{array}$ \\
\hline \multicolumn{5}{|c|}{ Donors : (1) Control, normal dogs } \\
\hline Rats: Before & $\begin{array}{l}14 \cdot 9 \pm 0 \cdot 15 \\
14 \cdot 6 \pm 0.18\end{array}$ & $\begin{array}{r}45 \cdot 0 \pm 0 \cdot 30 \\
44 \cdot 4 \pm 0.18\end{array}$ & $\begin{array}{l}8 \cdot 4 \pm 0 \cdot 26 \\
8 \cdot 7 \pm 0 \cdot 13\end{array}$ & $\left|\begin{array}{l}1 \cdot 1 \pm 0 \cdot 17 \\
1 \cdot 3 \pm 0 \cdot 21\end{array}\right|$ \\
\hline Rats: $\begin{array}{c}\text { Before } \\
\text { After }\end{array}$ & $\begin{array}{l}13 \cdot 8 \pm 0 \cdot 19 \\
14 \cdot 9 \pm 0 \cdot 16^{*}\end{array}$ & $\begin{array}{l}40.8 \pm 0.88 \\
45.1 \pm 0.46\end{array}$ & $\mid \begin{array}{l}7 \cdot 8 \pm 0 \cdot 23 \\
7 \cdot 9 \pm 0 \cdot 14\end{array}$ & $\left|\begin{array}{l}2 \cdot 2 \pm 0 \cdot 21 \\
1 \cdot 7 \pm 0 \cdot 19\end{array}\right|$ \\
\hline Rats: Before & $\begin{array}{l}14 \cdot 5 \pm 0 \cdot 19 \\
15 \cdot 7 \pm 0 \cdot 15\end{array}$ & $\begin{array}{l}44 \cdot 0 \pm 0 \cdot 63 \\
47 \cdot 3 \pm 0 \cdot 35 *\end{array}$ & $\begin{array}{l}8 \cdot 1 \pm 0 \cdot 23 \\
9 \cdot 5 \pm 0 \cdot 23^{*}\end{array}$ & $\begin{array}{l}1 \cdot 5 \pm 0 \cdot 27 \\
1 \cdot 4 \pm 0.18\end{array}$ \\
\hline Rats: $\begin{array}{c}\text { Before } \\
\text { After }\end{array}$ & $\begin{array}{l}\text { Hypoxic dog } \\
13 \cdot 5 \pm 0 \cdot 17 \\
15 \cdot 0 \pm 0 \cdot 17\end{array}$ & $\begin{array}{l}41 \cdot 5 \pm 0 \cdot 51 \\
45 \cdot 5 \pm 0 \cdot 56^{*}\end{array}$ & $\begin{array}{l}8 \cdot 0 \pm 0 \cdot 19 \\
8 \cdot 3 \pm 0 \cdot 15\end{array}$ & $\begin{array}{l}2 \cdot 3 \pm 0 \cdot 21 \\
2 \cdot 9 \pm 0.26\end{array}$ \\
\hline
\end{tabular}

* Indicates probability value, $P<0.01$ for means 'after' as com. pared to those 'before'.

by the methods of Borsook ${ }^{3}$, and Gordon ${ }^{4}$. This plasma preparation, pooled from each group, was injected intraperitoneally, in doses of $1.0 \mathrm{ml} . / 100 \mathrm{gm}$. day, for 7-9 days into 200 -gm. female SpragueDawley rats the hæmatological values of which had been determined. Terminally blood was removed by cardiac puncture from the 20 rats in each recipient group for determination of hæmoglobin, hæmatocrit, erythrocyte and reticulocyte values. The results in Table 1 indicate that the plasma from all donor groups, excepting that of the control animals, produced erythropoietic stimulation in the recipients. Additionally, the plasma of the phenylhydrazinetreated group stimulated erythrocyte production. In no case was reticulocyte percentage increased. The dog, like other animals, responds to appropriate stimuli by increased production of the erythropoietic-stimulating factor.

This investigation was supported in part by a grant from the National Institutes of Health, U.S. Public Health Service.

\section{F. W. KInARD \\ F. F. GRIFFIN, JUN. \\ F. W. KINARD, JUN.}

Medical College of South Carolina, Charleston, South Carolina.

${ }^{1}$ Linman, J. W., Bethell, F. H., and Long, M. J., J. Lab, und Clin. Med., 51, 8 (1958).

${ }^{2}$ Gibell, C., Arch. Exp. Path. Pharmakol., 65, 284 (1911).

Borsook, H., Graybiel, A., Keighley, G., and Windsor, E., Blood, 9, 734 (1954).

4 Gordon, A. S., Piliero, S. J., Kleinberg, W., and Freedman, H., Proc. Soc. Exp. Biol. and Med., 86, 255 (1954).

\section{Ackee Toxin : a Riboflavin Antimetabolite?}

There has occurred in Jamaica an illness known as 'vomiting sickness', characterized by vomiting, coma and death, which has been attributed to a toxin present in the ackee (Blighia sapida) ${ }^{1-3}$. In the course of routine assay for the protein values of human diets, a Jamaican meal containing this fruit was prepared, fed to rats, and the animals lost 26 per cent of their initial body-weight in 10 days. On a dry-weight basis, the meal contained 39 per cent green banana, 26 per cent salted cod-fish, 9 per cent coco-nut oil, 6 per cent salted pork fat, and 20 per cent ackee. Despite the high total protein content (17 per cent) of this mixture, it has a net dietaryprotein value ${ }^{4}$ of zero. 